\title{
EFFECT OF NEBULIZER AND EFFECTIVE COUGH ON THE STATUS OF BREATHING COPD PATIENTS
}

\author{
Lutfi Wahyuni \\ STIKES BINA SEHAT PPNI MOJOKERTO
}

\begin{abstract}
COPD is characterized by air flow resistance in the respiratory tract that is not fully reversible. This air flow resistance is progressive and associated with lung inflammatory processes of the particles or toxic gases or disaster. Giving nebulizer and effective cough in COPD patients to facilitate clearance of bronchial those help to control the inflammatory process and improve the function of ventilation, and if action to combined nebulizer and effective cough form of ventilation can increase the function. The design used this study use pre experimental one-group pre test - post test design. In this study the target population is COPD patients in the Pajajaran RSUD Prof Dr Soekandar Mojosari.The samples in this study are 20 respondents, that are taken by using the technique sampling.That meet the criteria for inclusion and independent exclusion.The variabel in this study is a combination of nebulizer and effective cough, whereas the dependent variable is the status of respiratory, which were collected by using observation sheets and analyzed using Willcoxon Sign Rank Test with significance level $p<0.05$. The result show that giving nebulizer and effective cough influence have the increase in respiratory status of COPD patients is ( $p=$ 0.001). It can be concluded that nebulizer and effective cough can improve the respiratory status of COPD patients.
\end{abstract}

Key words: Nebulizer, effective cough, respiratory status COPD patients

\section{Pendahuluan}

Chronic Obstructive Pumonaly

Disease atau Penyakit Paru Obstruktif Kronik merupakan keadaan yang ditandai dengan kelemahan kemampuan untuk bernapas, mereka yang menderita COPD akan menanggung akibat dari kurangnya oksigen. Penurunan kadar oksigen dalam sirkulasi dan jaringan tubuh, menempatkan pasien pada risiko tinggi terhadap beberapa kondisi serius lainnya. Bila COPD menunjukkan keadaan ketidak seimbangan antara perbaikan paru dan mekanisme pertahanan diri menyebabkan fibrosis jalan nafas perifer, sehingga rusaknya struktur bronkiolus dan melebarnya alveoli yang nantinya menyebabkan meningkatnya tahanan dijalan napas perifer, akhirnya terjadi obstruksi sehingga memperberat penyempitan jalan napas akibat adanya edema dan hipersekresi mucus (Brunner \& Suddarth, 2002). Berdasakan data WHO menunjukkan bahwa COPD menempati urutan ke 6 sebagai penyebab utama kematian di dunia, sedangkan pada tahun 2002 telah menempati urutan ke 3 setelah penyakit Kordivaskoler dan kanker. Pada tahun 2004 hasil survei direktorat Jendral PPM bahwa COPD menempati urutan pertama penyumbangkan angka kesakitan (35 \%). Selain itu didapatkan juga data laporan rawat inap ruang Pajajaran RSUD Prof Dr Soekandar Mojosari bahwa .jumlah pasien COPD menduduki peringkat ke 2 dari 10 besar penyakit paru yaitu sejumlah 215 pasien COPD.

\section{Tujuan}

Menganalisis Efektifitas pemberian nebulizer dan batuk efektif terhadap status pernafasan pasien COPD di Pajajaran RSUD Prof Dr Soekandar Mojosari .

\section{Metode}

Desain yang digunakan dalam penelitian ini adalah Pra-eksperimen one-group pra test post test design yaitu mengungkapkan hubungan sebab akibat dengan cara melibatkan satu kelompok subyek. Kelompok 
subyek diobservasi sebelum dilakukan intervensi, kemudian diobservasi lagi setelah intervensi. Penelitian dilakukan pada bulan November 2014 di Pajajaran RSUD Prof Dr Soekandar Mojosari dengan Populasinya adalah semua pasien COPD di ruang Pajajaran RSUD Prof Dr Soekandar Mojosari. Sampel: sebagian pasien COPD di ruang Pajajaran RSUD Prof Dr Soekandar Mojosari sebanyak 20 responden, Sampling yang digunakan adalah purposive sampling yaitu Tehnik penetapan sampel dengan cara memilih sampel diantara populasi sesuai dengan yang dikehendaki peneliti. Variabel independen pada penelitian ini adalah pemberian nebulizer dan batuk efektif, Varibel dependen pada penelitian ini adalah status pernafasan pasien COPD. Setelah didapatkan nilai dari masing-masing variabel, kemudian ditabulasikan ke dalam tabulasi silang. Selanjutnya dianalisis dengan menggunakan uji Willcoxon Sign Rank Test untuk mengetahui efektivitas pemberian nebulizer dan batuk efektif terhadap status pernafasan pasien COPD.

\section{Hasil dan Pembahasan}

1. Status pernafasan responden sebelum Pemberian nebulezer dan batuk efektif

Tabel 1

\begin{tabular}{lll}
\hline Pernafasan & Frew & \% \\
\hline Normal & - & - \\
Menurun & 20 & $100 \%$ \\
\hline
\end{tabular}

Berdasarkan tabel diatas dapat dilihat bahwa status pernafasan responden sebelum pemberian nebulezer dan batuk efektif seluruhnya menurun sebanyak 20 responden $(100 \%)$.

2. Status pernafasan responden setelah Pemberian nebulezer dan batuk efektif

Tabel 2

\begin{tabular}{lll}
\hline Pernafasan & Frew & \% \\
\hline Meningkat & 15 & $75 \%$ \\
Menurun & 5 & $25 \%$ \\
Total & 20 & $100 \%$ \\
\hline
\end{tabular}

Berdasarkan tabel diatas dapat dilihat bahwa status pernafasan sesudah dilakukan pemberian nebulizer dan batuk efektif sebagian besar status pernafasan meningkat atau menjadi $75 \%$ atau 15 responden dan status pernafasan menurun sebanyak 5 responden $(25 \%)$.
3. Efectivitas pemberian Pemberian nebulezer dan batuk efektif terhadap pasien COPD

Tabel 3

\begin{tabular}{lll}
\hline Pernafasan & Sebelum & Sesudah \\
\hline $\mathbf{X}$ & $\mathrm{X} 1 \quad=\mathrm{X} 2=8,1248$ \\
& 15,4165 & \\
SD & 1,9982 & 1,4836 \\
Wilcoxon test nilai sig (2-tailed) $=\mathbf{0 , 0 0 1}$ \\
\hline \multicolumn{3}{r}{ Berdasarkan tabel di atas dapat }
\end{tabular}

Berdasarkan tabel di atas dapat diketahui nilai rata-rata sebelum diberikan nebilizer dan batuk efektif adalah X1 = 15,4165 dan nilai standar deviasinya 1,9982 . Sedangkan nilai rata-rata setelah diberikan nebulizer dan batuk efektif X2 $=8,1248$ dan nilai standar deviasinya 1,4836. Hasil uji statistik menunjukkan nilai sig (2-tailed)

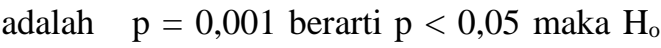
ditolak dan $\mathrm{H}_{1}$ diterima artinya Efektif pemberian nebulizer dan batuk efektif terhadap status pernafasan pasien COPD.

1. Status Pernafasan Pasien COPD. Sebelum Pemberian Nebulizer dan Batuk Efektif

Dari tabel 1 menunjukkan status pernafasan pasien PPOK sebelum dilakukan pemberian kombinasi bronkodilator aerosol dan batuk efektif seluruhnya atau 100\% menurun. Penurunan status pernafasan ini terjadi disebabkan keterbatasan aliran udara (terutama aliran ekspirasi) yang tidak sepenuhnya reversibel. Keterbatasan aliran udara terjadi progresif dan berkaitan dengan respon peradangan yang abnormal terhadap partikel atau gas-gas berbahaya, terutama asap rokok

2. Status Pernafasan Pasien COPD Sesudah Pemberian nebulizer dan Batuk Efektif

Dari tabel.2 menunjukkan kadar status pernafasan pasien COPD sesudah dilakukan pemberian nebulizer dan Batuk Efektif sebanyak 15 responden $(75 \%)$ mengalami peningkatan atau menjadi lebih baik.. Hal ini disebabkan karena responden tersebut benar - benar telah mendapatkan terapi bronlodilator aerosol dan batuk efektif.Namun ada 5 responden (25\%) yang mengalami penurunan status pernafasan.

3. Efektivitas Pemberian nebulizer dan Batuk Efektif Terhadap Status Pernafasan Pasien COPD

Nebulizer adalah alat yang dapat mengubah obat yang berbentuk larutan menjadi aerosol secara terus- menerus dengan tenaga yang berasal dari udara yang dipadatkan atau 
gelombang ultrasonik. Aerosol yang terbentuk dihirup penderita melalui mouth piece atau sungkup. Merupakan salah satu penggunaan terapi inhalasi (pemberian obat ke dalam saluran pernafasan dengan cara inhalasi).Sedangkan bronkodilator yang diberikan dengan nebulizer memberikan efek bronkodilatasi yang bermakna tanpa menimbulkan efek sampingSelain itut ujuan pemberian nebulizer adalah untuk mengurangi sesak, untuk mengencerkan dahak, bronkospasme berkurang atau menghilang dan menurunkan hiperaktivitas bronkus serta mengatasi infeksi dan untuk pemberian obat-obat aerosol atau inhalasi.Dari sini diketahui bahwa jenis nebulizer yang digunakan di ruang Mawar Merah Sidoarjo adalah Simple nebulizer dimana nebulizer ini menghasilkan partikel yang lebih halus, yakni antara $2-8$ mikron. Biasanya tipe ini mempunyai tabel dan paling banyak dipakai di rumah sakit. Beberapa bentuk jet nebulizer dapat pula diubah sesuai dengan keperluan sehingga dapat digunakan pada ventilator dimana dihubungkan dengan gas kompresor.

\section{Kesimpulan}

Ada pengaruh pemberian nebulizer dan batuk efektif terhadap status pernafasan pasien COPD dengan hasil uji statistik menunjukkan nilai sig (2-tailed) adalah $\mathrm{p}=0,001$, berarti $\mathrm{p}<0,05$.

\section{DAFTAR PUSTAKA}

Alsagaff, Hood dkk. 2009. Dasar-dasar Ilmu Penyakit Paru. Surabaya : Airlangga University Press

Arikunto, S 2002. Prosedur Penelitian Suatu Pendekatan Praktek. Jakarta: Rineke Cipta

Brunner \& Suddarth. 2002. Buku Ajar Keperawatan Medikal Bedah. Jilid I. Jakarta : EGC

Carpenito, Lynda Jual. 1998. Diagnosa Keperawatan Aplikasi Pada Praktek Klinis Edisi 6. Jakarta: EGC

Dorland. 1996. Kamus Kedokteran. Jakarta : EGC

Ganong WF. 2005. Buku Ajar Fisiologi Kedokteran. Jakarta : EGC
Setyabudi, dkk. 2001. Terapi Inhalasi. Http : WWW.Pharmacy.com. Diakses pada tanggal 29 Juli 2010

Nursalam. 2001. Proses dan Dokumentasi Keperawatan. Jakarta : Salemba Medika

Nursalam. 2003. Konsep dan Penerapan Metodologi Penelitian Ilmu Keperawatan. Jakarta : Salemba Medika

Nursalam. 1998. Karya Tulis Penelitian : Pedoman Praktis Penyusunan. Surabaya

Perhimpunan Dokter Paru Indonesia. 2003. Pedoman Diagnosis Dan Penatalaksanaan PPOK di Indonesia.

Potter, Perry. 2005. Fundamental Keperawatan. Jakarta : EGC

Price \& Wilson. 2000. Buku Ajar Patofisiologi. Jakarta : EGC

Rab T. 2004. Prinsip Gawat Paru. Jakarta : Hipokrates

Rab T. 2007. Ilmu Penyakit Paru. Jakarta : Hipokrates 